\title{
Does Sphenoid Pneumatization Affect the Angle of the Eustachian Tube?
}

\author{
Sfenoid Sinüs Pnömatizasyonu Östaki Tüpü Açısını \\ Etkiliyor mu?
}

\begin{abstract}
Aim: In this study, we aimed to investigate the relationship between sphenoid sinus pneumatization and the angle of the Eustachian tube.

Methods: The study included a total of 158 patients. The Eustachian tube angle (ETA) was measured and sphenoid pneumatization was classified in the coronal plane.

Results: According to the coronal classification of sphenoid pneumatization, 52 (16\%) hemisphenoids were type 1, 177 (56\%) hemi-sphenoids were type 2, and 87 (27.5\%) hemi-sphenoids were type 3. According to the sagittal classification, 24 (7.6\%) hemi-sphenoids were pre-sellar, 101 (32\%) hemi-sphenoids were sellar, and 191 (60.4\%) hemi-sphenoids were postsellar. The mean ETA in coronal classification was $24.71 \pm 3.35,25.03 \pm 3.24$, and $25.90 \pm 3.10$ degrees for the type 1, type 2, and type 3 classes, respectively. The angle showed a gradual increase from type 1 to type 3 , and it was found that ETA was statistically significantly wider in cases with lateral recess pneumatization (type 3, post-rotundum) than in type 2 and type 1 pneumatizations ( $p=0.039, p=0.035$, respectively).
\end{abstract}

Conclusion: ETA is increased in patients with lateral recess pneumatization.

Keywords: anatomy; Eustachian tube; sphenoid sinus

\section{Öz}

Amaç: Bu çalıșmada sfenoid sinüs pnömatizasyonu ile Östaki tüpünün açısı arasındaki ilișkiyi araștırmak amaçlanmıștır.

Yöntem: Çalıșma toplam 158 hasta içerdi. Östaki tüpü açısı (ÖTA) ölçüldü ve sfenoid pnömatizasyonu koronal planda sınıflandırıldı.

Bulgular: Sfenoid pnömatizasyonunun koronal tasnifine göre 52 (\%16) hemi-sfenoid tip 1, 177 (\%56) hemi-sfenoid tip 2 ve 87 (\%27,5) hemi-sfenoid tip 3 idi. Sagital tasnife göre $24(\% 7,6)$ hemi-sfenoid pre-sellar, 101 (\%32) hemi-sfenoid sellar ve $191(\% 60,4)$ hemi-sfenoid post-sellar idi. Koronal tasnifte ortalama ÖTA tip 1, tip 2 ve tip 3 sınıfları için sırasıyla 24,71 23,$35 ; 25,03 \pm 3,24$

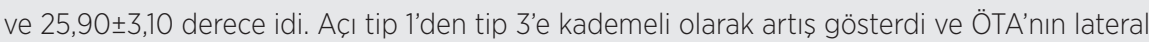
reses pnömatizasyonlu hastalarda (tip 3, post-rotundum) tip 2 ve tip 1 pnömatizasyonlara kıyasla istatistiksel olarak anlamlı biçimde daha geniș olduğu tespit edildi (sırasıyla p=0,039; $\mathrm{p}=0,035$ ).

Sonuç: Lateral reses pnömatizasyonlu hastalarda ÖTA artmaktadır.

Anahtar Sözcükler: anatomi; Östaki tüpü; sfenoid sinüs
Fakih Cihat Eravci ${ }^{1,2}$, Gulsum Kubra Yildirim³, Kursat Murat Ozcan², Mustafa Colak', Selcuk Parlak', Mehmet Fatih Karakus ${ }^{4}$, Suleyman Emre Karakurt ${ }^{2}$, Aykut İkinciogullari², Haci Huseyin Dere ${ }^{2}$

1 Department of Otorhinolaryngology, Meram Medical Faculty, Necmettin Erbakan University

2 Department of Otorhinolaryngology, Ankara Numune Training and Research Hospital

${ }^{3}$ Department of Radiology, Ankara Numune Training and Research Hospital

${ }^{4}$ Department of Otorhinolaryngology, Faculty of Medicine, Ordu University

Received/Gelis : 09.12.2020 Accepted/Kabul: 28.03.2021

DOI: 10.21673 /anadoluklin.842503

Corresponding author/Yazışma yazarı Fakih Cihat Eravcı

Hocacihan Mah., Abdulhamid Han Cad. 3, 42080 Konya, Turkey

E-mail: fceravci@gmail.com

\section{ORCID}

Fakih Cihat Eravci: 0000-0001-9092-7923 Gulsum K. Yildirim: 0000-0003-1894-9372 K. Murat Ozcan: 0000-0002-5262-0565 Mustafa Colak: 0000-0002-3191-4134 Selcuk Parlak: 0000-0002-3318-7399 M. Fatih Karakus: 0000-0002-6264-5416 S. Emre Karakurt: 0000-0002-3394-8119 Aykut Ikinciogullari: 0000-0001-5786-7092 Haci Huseyin Dere: 0000-0003-0750-9590 


\section{INTRODUCTION}

The Eustachian tube (ET) is located at the junction between the ear and nasopharynx and is critical for the regulation of middle ear pressure. Also, it has protection (from nasopharyngeal secretion and sound pressure) and clearance functions for the middle ear. With these functions, it plays an important role in the middle ear physiology. Impairment of these functions leads to the development of otitis media due to negative pressure and contamination with microorganisms. If the dysfunction continues, chronic illness and complications may occur.

The anatomical features and angle of the ET, which is composed of cartilage and bone segments, are critical for the performance of its functions. The Eustachian tube angle (ETA) is more horizontal and shorter in children than in adults (1). Increased ETA has been reported to be one of the factors decreasing the frequency of otitis media in adults (2). Studies have shown that the ET is short, more horizontal and floppy in groups at risk for otitis media (such as individuals with Down's syndrome and craniofacial anomalies) (3). It has also been reported that a more horizontal ET may contribute to the development of chronic otitis media (4). As a result, ETA is one of the determinant anatomical features for ET functions. In addition, it has been reported to play an important role in preventing nasopharyngeal reflux in the middle ear $(3,5)$.

Sphenoid sinuses are highly variable in their configuration. Traditionally, sphenoid aeration has been classified in the sagittal plane corresponding to the extension of pneumatization around the sella turcica. This classification has three types: conchal, pre-sellar, and sellar (6). "Post-sellar" has also been defined in another classification, resulting in four levels in the sagittal plane (7). However, pneumatization of the sphenoid can extend in different directions, where the greater sphenoid wing, posterior orbital wall, pterygoid processes and lesser sphenoid wing can be affected (8). The greater sphenoid wing and pterygoid process pneumatization result in a recess that is termed specifically as the lateral recess. This recess refers to the sphenoid pneumatization lateral to the plane between the Vidian canal and foramen rotundum and, according to this plane, a new practical coronal sphenoid classification has been established (9).
The squamous and petrous parts of the temporal bone and the greater wing of the sphenoid bone together constitute the osseous portion of the ET, and the ET opens into the nasopharynx along the posterior edge of the medial pterygoid plate. In addition, it is known that sphenoid aeration can extend to the greater wing and pterygoid process. However, to our knowledge, no study has yet investigated this close relationship and how ETA is affected by sphenoid aeration, particularly lateral recess pneumatization. The present study aimed to investigate this relationship of sphenoid pneumatization and ETA against the Frankfort horizontal plane.

\section{MATERIALS AND METHODS Participants}

We retrospectively reviewed the temporal CT scans of 158 consecutive patients who presented to our otolaryngology clinic at the Ankara Numune Training and Research Hospital with various ear problems (e.g., chronic otitis media with or without suppuration, conductive hearing loss, otalgia) between 2013 and 2016. Inclusion criteria were age $>18$ years, no history of trauma, sphenoid infection and otologic and rhinologic surgery, and availability of $0.5 \mathrm{~mm}$ multislice CT images with coronal reconstructions. A total of 316 Eustachian tubes and hemi-sphenoid sinuses were evaluated. Patient data (age, sex, extent of sphenoid pneumatization, and ETA) were obtained retrospectively.

\section{Measurements}

A 64-slice multidetector CT system (Aquilion, Toshiba Medical Systems, Shimoishigami, Otawara-Shi, Japan) was used for CT imaging and the images were evaluated and the parameters were measured on the Aquarius Workstation V3.6 (TeraRecon, San Mateo, CA, USA). Imaging parameters included a slice thickness and reconstruction interval of $0.5 \mathrm{~mm}$, and a field of view of $21.8 \times 28.8 \mathrm{~cm}$. Images ranging from 200 to 400 slices were reconstructed using a classical filtered back-projection. The images were evaluated and measured separately by two experienced radiologists. The sagittal and coronal sphenoid classifications were accepted based on consensus and the ETA was calculated as the mean of two separate angle measurements. 
Table 1. The mean hemi-sphenoid sinus volumes and Eustachian tube angles according to each sphenoid (sagittal and coronal) class and multiple-comparison statistical analyses

\begin{tabular}{|c|c|c|c|c|}
\hline & $\begin{array}{l}\text { Mean hemi-sphenoid } \\
\text { volume }\left(\mathrm{cm}^{3}\right)\end{array}$ & $\begin{array}{l}\text { Eustachian tube } \\
\text { angle }\left({ }^{\circ}\right)\end{array}$ & $\begin{array}{l}\text { One-way } \\
\text { ANOVA }\end{array}$ & $\begin{array}{l}\text { Post hoc (Tukey) } \\
\text { test }\end{array}$ \\
\hline \multicolumn{5}{|l|}{ Sagittal classification numbers (n) } \\
\hline Conchal $(n=0)$ & - & - & & \\
\hline Pre-sellar $(n=24)$ & $1.20 \pm 0.72(0.10-3.10)$ & $24.75 \pm 4.00$ & & \\
\hline Sellar $(n=101)$ & $2.96 \pm 1.43(0.30-7.30)$ & $25.38 \pm 3.27$ & & \\
\hline Post-sellar $(n=191)$ & $5.71 \pm 2.50(0.70-15.00)$ & $25.19 \pm 3.13$ & $\mathrm{p}=0.678$ & \\
\hline Coronal classification numbers (n) & & & & $\begin{array}{l}(\text { Type III }- \text { Type II })= \\
\mathbf{p}=\mathbf{0 . 0 3 9}\end{array}$ \\
\hline Type I (pre-Vidian) $(\mathbf{n}=52)$ & $2.36 \pm 1.50(0.10-7.60)$ & $24.71 \pm 3.35$ & & $($ Type III - Type I $)=$ \\
\hline Type II (pre-rotundum) (n=177) & $4.15 \pm 2.23(0.50-10.10)$ & $25.03 \pm 3.24$ & & $\mathrm{p}=0.035$ \\
\hline Type III (post-rotundum) $(\mathrm{n}=87)$ & $6.45 \pm 2.65(1.90-15.00)$ & $25.90 \pm 3.10$ & $\mathrm{p}=\mathbf{0 . 0 4 9}$ & $\begin{array}{l}(\text { Type I }- \text { Type II })= \\
p=0.527\end{array}$ \\
\hline
\end{tabular}

In sphenoid pneumatization classification, each side of the sphenoid is separated into 4 groups in the sagittal plane and 3 groups in the coronal plane. The sagittal plane sphenoid pneumatization is classified according to the aeration of the sella turcica (conchal, pre-sellar, sellar or post-sellar classes) $(6,7)$. In the coronal plane, the lateral recess pneumatization is classified according to the plane between the Vidian canal (VC) and foramen rotundum (FR), as previously described (9). Type I (pre-Vidian) refers to pneumatization extending from the midline to the medial edge of the VC (Figure 1: Patient 1, Image a, left hemi-sphenoid). Type II (pre-rotundum) refers to pneumatization extending to the lateral edge of the FR (Figure 1: Patient 1, Image a, right hemi-sphenoid, and Patient 2, Image a, left hemi-sphenoid), and type III (post-rotundum) refers to pneumatization extending to the lateral edge of the FR (Figure 1, Patient 2, Image a, right hemi-sphenoid). The sphenoid sinus volumes were calculated automatically with a volume-rendering technique on the Aquarius Workstation V3.6. The mean volumes of the bilateral sphenoid sinuses were calculated separately.

The multiplanar reconstruction (MPR) technique was used for ETA measurements. Images were standardized for all patients through the angle of reformatted image and adjusted until the basal turns of the cochlea were seen to be equal in both coronal and axial planes. The axial images were also adjusted in an anterior posterior direction with reference to the Frankfort line, defined as the connection of the left infraorbital margin with both upper margins of the external audi- tory meatus. The orifices of the ET (tympanic and pharyngeal) were identified on the axial slices. Each ETA was defined as described in previous studies $(4,10)$; the pharyngeal orifice of the ET lumen was the point nearest the pharynx where a loop-shaped lumen appeared, the tympanic orifice was the point on the ET closest to the appearance of the external auditory canal on a cross-sectional image. ETA was defined as the angle made by a straight line drawn through the ET lumen intersecting the Frankfort line.

\section{Statistical analysis}

Statistical analysis was performed using the SPSS (v. 22) software (SPSS, Chicago, IL, USA). Normal distribution was assessed by the KolmogorovSmirnov test. Continuous variables were presented as mean \pm standard deviation and discrete variables as frequencies and percentages. Each side of the ET and hemi-sphenoid sinus was included in the analyses separately. Hemi-sphenoid sinus aeration was classified into 4 groups in the sagittal plane and 3 groups in the coronal plane as described previously. One-way analysis of variance (ANOVA) was used to compare ETAs of the sagittal and coronal classes. The Tukey test was used for post hoc testing after one-way ANOVA for multiple comparisons. $\mathrm{p}<0.05$ was considered statistically significant.

\section{Study ethics}

The study protocol was approved by the Clinical Research Ethics Committee of the Ankara Numune Training and Research Hospital, University of Health 
Sciences (approval no: 1894-2018). The study was conducted in accordance with the principles of the Declaration of Helsinki.

\section{RESULTS}

The study included a total of 158 patients (81 males, 77 females), with a mean age of $39.59 \pm 13.87$ (18-72) years. According to the coronal classification of sphenoid pneumatization, 52 (16\%) hemi-sphenoids were type 1, 177 (56\%) hemi-sphenoids were type 2, and 87 (28\%) hemi-sphenoids were type 3. According to the sagittal classification, 24 (7.6\%) hemi-sphenoids were pre-sellar, 101 (32\%) hemi-sphenoids were sellar, and $191(60.4 \%)$ hemi-sphenoids were post-sellar. The mean hemi-sphenoid sinus volumes for each class and the relationship of ETA to sphenoid pneumatization classes are shown in Table 1. No statistically significant correlation was found between ETA and sagittal classification groups $(\mathrm{p}=0.678)$. A statistically significant relationship was found between ETA and coronal classification groups $(\mathrm{p}=0.049)$ in one-way ANOVA. The second step post hoc test was applied to the coronal classification groups and ETA was found to increase gradually in the coronal sphenoid sinus classification, from type 1 to type 3, and it was found that ETA was statistically significantly wider in cases with lateral recess pneumatization (type 3 , post-rotundum) than in type 2 and type 1 pneumatizations $(\mathrm{p}=0.039, \mathrm{p}=0.035$, respectively). No difference was found between the ETA values of the type 2 and type 1 pneumatization groups $(\mathrm{p}=0.527)$ (Table 1$)$.

\section{DISCUSSION AND CONCLUSION}

The sphenoid sinus is located at the center of the cranium near vital structures. Sphenoid sinus pneumatization starts as early as 6 months of age and advances in posterior, inferior and lateral directions, which results in a broad variety of pneumatization types. The sphenoid sinus reaches its full size during adolescence (8). The expansion begins at the ostia and first the main sinus cavity is formed with the pneumatization of the body of the sphenoid. This anterior to posterior progression may extend into the dorsum

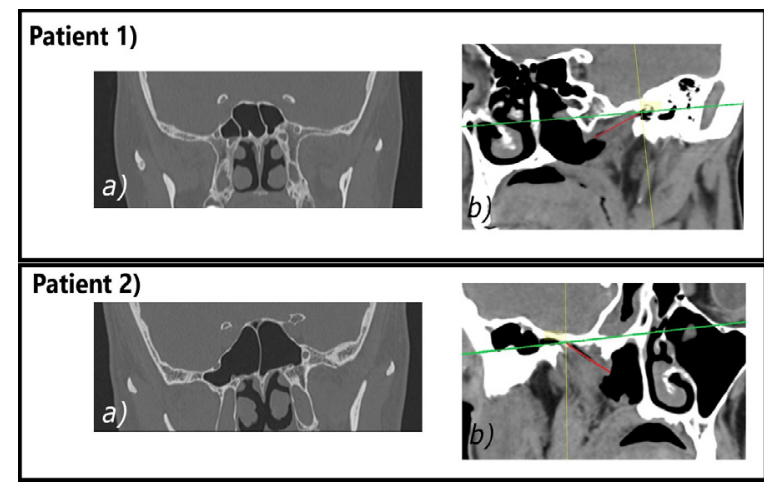

Figure 1. Examples from two patients show the type of pneumatization in the coronal plane on computed tomography and its relationship to the ipsilateral Eustachian tube angle (ETA). The images show (a) the coronal plane of the sphenoid and (b) the multiplanar reconstruction process of the computed tomography images.

Patient 1: image a) right sphenoid classified as type 2 and left sphenoid classified as type $1, \mathbf{b})$ the left ETA is narrow $\left(21^{\circ}\right)$. Patient 2: image a) left sphenoid classified as type 2 and right sphenoid classified as type $3, \mathbf{b}$ ) the right ETA is wider $\left(34^{\circ}\right)$. The green line is the line parallel to the Frankfort standard plane at the level of the Eustachian tube tympanic orifice and the red line is the line of the Eustachian tube lumen.

sella and clivus. There may also be pneumatization to lateral directions. As the sinus enlarges, some of the neighboring structures create bony prominences and related recesses inside the sinus. As one of the neighboring structures is the ET, these close relationships can affect each other during development and there are specific types of developmental ET anomaly that enter into the sphenoid body or sinus (11). The lateral recess is formed through the aeration of the pterygoid process and greater wing, and the foramen rotundum and Vidian canal create a prominence. The increase of the distance of these two prominences correlates with the pneumatization of the lateral recess. As it is known that facial nerve position changes with increased temporal bone pneumatization (12), the aim of this study was to investigate whether ETA is affected by an increase in sphenoid pneumatization, particularly lateral recess pneumatization. To our knowledge, no previous study has focused on this relationship.

The most widely used classification for sphenoid pneumatization is based on the extension of pneumatization around the sella turcica and comprises the conchal, pre-sellar, and sellar classes (6). This classification was the result of the transsphenoidal surgery focus on the sellar region. Some authors have further 
subdivided the sellar class into sellar and post-sellar classes, highlighting the extension of pneumatization beyond the sella posterior wall level (7). Together with the growing interest in the endoscopic endonasal approach to the middle cranial fossa, Meckel's cave and petrous bone, lateral pneumatization is taken into consideration. There have been attempts to classify lateral pneumatization and in a previous study it was simplified and the number of classes was reduced to $3(8,9)$. This classification is based on whether or not the aeration of the sphenoid extends the foramen rotundum and Vidian canal plane. In the present study, both sagittal and coronal plane sphenoid classifications were used and hemi-volumes were also measured.

The ET is composed of fibrocartilaginous and bony parts and its anatomical features have functional and physiological effects. Impairment of the tube function plays a role in middle ear pressure and may result in chronic otitis media. One of the anatomical features is the angle, which may play a critical role in the physiology (2-5). Compared with adults, the ET is more horizontal in children and the angle increases proportionally with age until 6-7 years of age (1). It has been speculated that this is the factor that decreases middle ear pathologies with age. There are also data that support this theory, showing that patients with Down's syndrome and craniofacial anomalies have a more horizontal ET and additional structural anomalies of the ET and have more middle ear disease (3). In addition, it has been found that a more horizontal ET might contribute to chronic otitis media $(4,13)$.

Previous studies involving ETA measurements focused on the role of the ET in patients with chronic otitis media (13-15). In those studies, the angle was measured according to a longitudinal line between external auditory canals and the longitudinal axis of the ET. Recent techniques allow simple and accurate ETA measurements. The MPR technique allows the angle to be measured precisely and, with measurement of the angle against the Frankfort line, the angle is measured in its anatomical position $(1,4)$. In the present study, ETA was measured precisely with the MPR technique and the relationship to sphenoid pneumatization was examined. The results showed that patients with type 3 (post-rotundum) lateral pneumatization in the coro- nal classification had an increased ETA. Therefore, it can be concluded that sphenoid lateral pneumatization might be an easy predictor of ETA and may indirectly play an important role in the ET function.

Furthermore, decreased mastoid volume has been shown to be a risk factor for otitis media, and vice versa. Mastoid pneumatization in patients with cystic fibrosis has been reported to be larger than in the normal population, suggesting a protective effect (16), whereas smaller mastoid pneumatization in patients with chronic otitis media suggests a susceptibility to middle ear pathologies (13). Therefore, there have been several studies focusing on mastoid aeration and its relationship to the ET, with some reporting contracted mastoid and chronic middle ear pathologies in association with more horizontal ETAs (13). Yegin et al. also reported a positive correlation between ET length and mastoid aeration (10), and stated that, though not to a statistically significant level, the mastoid volume increased with an increase in ETA. In addition to all these findings about the relationship between ET and mastoid aeration, Hindi et al. investigated the relationship between mastoid pneumatization and pneumatization of the sinuses, and reported a positive correlation only with sphenoid sinus pneumatization (17). Therefore, to be able to clarify these relationships, there is a need for studies to investigate all these parameters (ETA, mastoid pneumatization, and sphenoid pneumatization) together in larger series including different stages of chronic ear diseases.

In conclusion, the present study was the first to analyze the relationship between sphenoid pneumatization and ETA. Our results show that lateral recess pneumatization is associated with increased ETA. Therefore, the presence of sphenoid lateral pneumatization can give a clue about ETA and could therefore indirectly give an idea about ET function. Further studies are needed to verify these findings and investigate sphenoid lateral pneumatization in middle ear pathologies.

\section{Conflict-of-Interest and Financial Disclosure}

The authors declare that they have no conflict of interest to disclose. The authors also declare that they did not receive any financial support for the study. 


\section{REFERENCES}

1. Takasaki K, Takahashi H, Miyamoto I, Yoshida H, Yamamoto-Fukuda T, Enatsu K, et al. Measurement of angle and length of the Eustachian tube on computed tomography using the multiplanar reconstruction technique. Laryngoscope. 2007;117(7):1251-4.

2. Bluestone CD. Pathogenesis of otitis media: role of Eustachian tube. Pediatr Infect Dis J. 1996;15:281-91.

3. Verhoeff M, van der Veen EL, Rovers MM, Sanders EA, Schilder AG. Chronic suppurative otitis media: a review. Int J Pediatr Otorhinolaryngol. 2006;70(1):1-12.

4. Dinç AE, Damar M, Uğur MB, Öz II, Eliçora SŞ, Bişkin $S$, et al. Do the angle and length of the Eustachian tube influence the development of chronic otitis media? Laryngoscope. 2015;125(9):2187-92.

5. Ruhani K, Rälsänen S, Simonsen GS, Stenfors LE. Bacterial behaviour in middle ear effusion material: an in vitro study. Acta Otolaryngol. 1996;116(1):64-8.

6. Hamberger CA, Hammer G, Norlen G, Sjogren B. Transantrosphenoidal hypophysectomy. Arch otolaryngol. 1961;74(1):2-8.

7. Štoković N, Trkulja V, Dumić-Čule I, Čuković-Bagić I, Lauc T, Vukičević S, et al. Sphenoid sinus types, dimensions and relationship with surrounding structures. Ann Anat. 2016;203:69-76.

8. Wang J, Bidari S, Inoue K, Yang H, Rhoton Jr A. Extensions of the sphenoid sinus: a new classification. Neurosurg. 2010;66(4):797-816.

9. Vaezi A, Cardenas E, Pinheiro-Neto C, Paluzzi A, Branstetter IV BF, Gardner PA, et al. Classification of sphenoid sinus pneumatization: relevance for endoscopic skull base surgery. Laryngoscope. 2015;125(3):577-81.
10. Yegin Y, Çelik M, Simsek BM, Olgun B, Karahasanoglu A, Çolak C, et al. Correlation between the degree of the mastoid pneumatization and the angle and the length of the Eustachian tube. J Craniofac Surg. 2016;27(8):208891.

11. Falkenberg-Jensen B, Heimdal KR, Høgevold HE, Jablonski GE, Due-Tønnessen BJ, Hopp E. Abnormally wide Eustachian tubes involving the sphenoid bone: a collection. Laryngoscope Investig Otolaryngol. 2018;3(3):214.

12. Dai P, Zhang T, Wang K, Song J, Qian W, Wang Z. Positional relationship between the facial nerve and other structures of the temporal bone. J Laryngol Otol. 2004;118(2):106-11.

13. Sirikci A, Bayazit Y, Bayram M, Kanlikama M. Significance of the auditory tube angle and mastoid size in chronic ear disease. Surg Radiol Anat. 2001;23(2):91-5.

14. Kanzaki J, Taiji H, Kanke H, Shiga H. Evaluation of the Eustachian tube in normal subjects and in patients with otitis media with effusion by high-resolution computerized tomography. Auris Nasus Larynx. 1985;12:S52-S4.

15. Habesoglu TE, Habesoglu M, Bolukbasi S, Naiboglu B, Eriman M, Karaman M, et al. Does auditory tube angle really affect childhood otitis media and size of the mastoid? Int J Pediatr Otorhinolaryngol. 2009;73(5):747-9.

16. Todd NW, Martin WS. Temporal bone pneumatization in cystic fibrosis patients. Laryngoscope. 1988;98(10):1046-9.

17. Hindi K, Alazzawi S, Raman R, Prepageran N, Rahmat K. Pneumatization of mastoid air cells, temporal bone, ethmoid and sphenoid sinuses. Any correlation? Indian J Otolaryngol Head Neck Surg. 2014;66(4):429-36. 